around the world. Implementing these changes, and understanding more completely the causes of political violence and democratic breakdown, are tasks well worth our attention as a fitting memorial to one of the great political scientists of our day.

Steven E. Finkel

University of Virginia

Jerrold G. Rusk

University of Arizona

Mitchell A. Seligson

University of Pittsburgh

John Wahlke

University of Arizona

\section{Joann P. Paine}

Joann P. Paine, Associate Professor Emeritus at Southern Illinois University at Carbondale, died on April 11, 1995 in Waldport, Oregon. Joann was born on March 10, 1935, in Portland, Oregon. She earned her bachelor's degree from Whitman College in 1957, and then attended the University of Oregon where she earned her master's degree in 1963 and her Ph.D. in 1967. Like all of us in the academy, Joann "wore many hats" during her professional career. She was a woman, wife, mother, social advocate, contributing colleague, scholar, teacher, and friend.

As a woman, Joann was ahead of her time. She earned her Ph.D. in political science and became a university faculty member when that discipline was still composed almost exclusively of males. She was juggling the roles of "homemaker" and "career woman" long before that balancing act became fashionable. In recognition of her many contributions as a woman, Joann was listed in Who's Who of Young Women in America in 1968, International Who's Who of Women in 1976, and World's Who's Who of Women in 1977 and 1979.

Joann married Thomas Paine on February 2, 1957, in Tacoma, Washington. They were ideally suited for each other, and their marriage lasted until her death some 38 years later. As a wife Joann was always a true compan- ion. In her role as a mother, Joann raised six children-sons Robert, Thomas, Nicholas, and Patrick, and daughters Mary and Elizabeth. She also had seven grandchildren. As a mother she actively participated in all aspects of her children's lives, including serving on the Parent's Committee at her children's elementary school and serving as president of the Parent Teacher Association at her children's junior high school.

Joann was always involved in trying to develop a high degree of social consciousness in her university, profession, and community. As a social advocate within the university, Joann served on the Sexual Harassment Board and the Title IX Compliance Committee on Intercollegiate Athletics. Within the profession, she served on the MWPSA Committee on the Status of Women in the Profession, and within the broader community, her advocacy role included serving on the Steering Committee for Total School Integration.

If there was one thing for which Joann will always be remembered, it is for the seemingly endless energy which she poured into her role as a contributing colleague and member of the university community. In her years as a faculty member in the Department of Political Science at SIUC she served on a great many departmental committees, was the Director of Graduate Studies, and served as the adviser for Pi Sigma Alpha. In addition, she was endlessly giving of her time and talents to the broader university, including long-term service on both the Faculty Senate, many of its subcommittees, and the Student Conduct Review Board.

Joann's scholarly activities are best represented by the book Introduction to Systematic Political Science, which she co-authored with David Everson. That book complemented her role as a teacher, which I am sure she considered her first love (outside of her family). As a teacher she served on a great many master's thesis and Ph.D. dissertation committees, where she spent countless hours with students going over their written products. She was always developing new courses and reading in emerging areas of the discipline that provided her with new intellectual challenges. She enriched our department by developing and teaching a variety of what were then nontraditional courses, including Minority Politics, Urban Politics, Political Violence, and Computer Simulation.

My most vivid memories of Joann relate to her in the role of a friend. Joann began teaching at SIUC one year before me, and when I joined the faculty we very quickly became good friends. In the ensuing years we drank a lot of beer together with our graduate students, both of us believing that out-of-class socialization was an extremely valuable part of graduate education. We shared many concerns during the Vietnam war era, and we groped with the intellectual and ethical realities of the mass demonstrations and closing of the University in 1970. For several years after I joined the faculty at SIUC, Joann's husband Tom played fast pitch softball with me on a team that I managed, and my memory says Joann never missed a game-nor the pizza and beer afterwards. Over the years we enjoyed each other's company at countless departmental socials and graduate student gatherings. Tom and I both enjoyed banging on our guitars and singing folk tunes, and Joann would sit into the wee hours of the morning listening to us display our poor talents and talking with graduate students. She loved her dogs, her orchids, and quilting with the female senior citizens of the community. And some might say that she also just plain loved to "chat"with almost anyone, anytime, about anything.

Indeed, in her many roles Joann touched and made a difference in the lives of a great many persons. She will always be remembered by those who knew her, and will be missed dearly by those who loved her.

Roy E. Miller

Southern Illinois University at Carbondale 